Article

\title{
Elements of Sustainable Development in the Context of the Environmental and Financial Crisis and the COVID-19 Pandemic
}

\author{
Tomasz Kapecki \\ Faculty of Architecture, Institute of Architectural Design, Cracow University of Technology, \\ 31-155 Krakow, Poland; tomasz.kapecki@pk.edu.pl
}

Received: 17 June 2020; Accepted: 22 July 2020; Published: 31 July 2020

\begin{abstract}
Sustainable development is the need of the hour today. For over three decades, since the term was used in public little has been done about it. Such important activities for the protection of our ecosystem have been mainly discussed at scientific conferences or in the comfort of academic lecture halls. Successive global crises, especially the ecological, economic, financial and now humanitarian one related to the COVID-19 pandemic have demolished global economies, sidelined the development of a sustainable economy and especially sustainable construction, treating it more as a whim of the rich than expedience. The construction sector accounts for up to 40 per cent of the global carbon dioxide emissions and generates more than 0.5 billion tonnes of waste every year. However, when it comes to improving macroeconomic indicators after another crisis, the easiest way to look for savings is to use the production of emerging markets, without considering their lower economic and environmental awareness. Each time, the lust for profit prevailed over environmental protection. Education, business, and institutional factors failed, as indicated in the conclusions. That was the case until November 17, 2019, when the first man was infected with the coronavirus. Will we draw the right conclusions from that while facing a crisis unprecedented in human history? Can we change priorities from having to being?
\end{abstract}

Keywords: sustainable construction; environmental protection; financial crisis; economic crisis; coronavirus

\section{Introduction}

Sustainability is a capacious term for both sustainable economic development, including agricultural, regional and urban development, and sustainable housing. Sustainability involves harmonious actions consistent with nature, ecology oriented towards future generations. The world crises have a way of erupting with great force, destroying a whole network of well-functioning social, economic, financial and, especially significant, environmental relations. This happens because we do not see or do not want to see disturbing signals indicating a growing problem and the failure of the hitherto efficient system. Recovering from the crisis also often adopts a dynamic form, which aims at restoring the pre-crisis situation to be able to march north on the chart. This very often occurs at the expense of the weakest, cheap labour, the destruction of nature, ecosystems and even child labour. It is exactly through such actions that the global community will be increasingly plagued by humanitarian and health crises, the first example being the on-going COVID-19 epidemic. The coronavirus pandemic is likely to be followed by even more deadly and devastating outbreaks of diseases, unless their root cause - the violent destruction of the natural world—is abruptly stopped, leading biodiversity experts warn [1]. One of the basic actions that can contribute to the improvement of the current situation is education, i.e., making us aware of the threats that await us and building social solidarity of global 
importance. The final conclusions presented in the article do not solve the problem but are important, as they indicate the course of action.

\section{Objective and Method}

The subject matter resulted from the research and professional premises of a practising architect. The main objective of the study was to analyse the impact of environmental, financial, and humanitarian crises on sustainable development, especially housing. It identifies the negative market mechanisms associated with crisis recovery, which have a significant impact on environmental protection and even human life. The paper is based on literature studies, statistical data, and critical and comparative analysis, which have led to the formulation of conclusions, and addresses the ethical issues that link the business world and society inextricably. While describing the environmental crisis, the main focus was on the analysis of the Chinese economy, the second largest economy in the world and the country with the largest emissions to the atmosphere. Since 2004, China has had the largest carbon footprint; pressure from the international community as well as from within has led the Chinese authorities to commit themselves to reducing the intensity of greenhouse gases by about $65 \%$ by 2030 in the Paris Agreement (2016), transforming it from being the largest poisoner to a leader in sustainable development. Due to their effectiveness, the changes taking place in the Chinese economy should, therefore, be analysed comprehensively, as their scale and effects are unparalleled with any other country in the world. The data related to the financial crisis, commonly referred to as the 2007 subprime mortgage crisis, mainly concern the USA, as the source of problems that later spread around the world was located there. It is the largest real estate market, of predominantly single-family houses, and its size and the wealth of its citizens had great potential to promote and implement sustainable housing during the return to normality. The humanitarian Covid-19 crisis is new, and one does not even know what stage it is at. Therefore, the data in the paper concerns mainly European countries, being the most reliable and partially stabilized ones, as compared to the data from China or from Latin American countries, where currently the number of deaths breaks down further barriers every day.

\section{Results}

\subsection{The Environmental Crisis}

Environmental pollution has been present for several decades, and part of the population has become accustomed to this fact, treating it as an immanent part of our existence on earth. Due to their actions focused mainly on living comfort and economic benefits, people have transformed $2 / 3$ of their ecosystems for their needs [2]. For several years now, we have been experiencing the effects of the global environmental and climatic crisis more and more acutely. One of the causes of the environmental crisis is the still high emission of carbon dioxide $\mathrm{CO}_{2}$ into the atmosphere, as a by-product of industry and electricity production. Let the data speak for itself. After rapid global growth of almost $40 \%$ in the first decade of the 21st century from 22 to 30 gigatonnes (GT), the second decade brings a flattened growth rate of about 33 GT on average, according to the latest report published in 2019 by the International Energy Agency [3]. An extremely important element of this data is the visible decrease in $\mathrm{CO}_{2}$ emissions in high-economy countries, which confirms the rightness of their development strategies based on respect for the environment by introducing elements of a sustainable economy in which land resources are not exploited faster than nature renews them. This applies mainly to industries related to fossil fuel-based power generation but also the construction industry. What is worrying, however, is the continuing increase in $\mathrm{CO}_{2}$ emissions in less affluent countries, which rose from $10.5 \mathrm{GT} \mathrm{CO}_{2}$ to $22 \mathrm{GT}$ $\mathrm{CO}_{2}$ from 2010 to 2019, sending a clear signal to rich societies and international organisations that, in the face of the environmental crisis, only joint action is the most rational and effective direction. Unfortunately, it meets with resistance, resulting from the need to invest in new expensive technologies, which slows down the process of enrichment of communities in poorer countries. The largest contributor to carbon dioxide emissions in the world is the construction industry. In total, buildings and construction 
account for 39\% of total carbon emissions (World Green Building Council (WGBC)) [4]. Emissions from the energy used to heat and cool buildings account for $28 \%$. The remaining $11 \%$ of carbon dioxide emissions come from building processes throughout the life cycle of a building-construction, alteration, renovation (WGBC). Therefore, the promotion of the development and use of low-carbon construction materials and services, the energy efficiency of construction machinery, and the use of renewable energy have been identified as the three main potential ways to reduce carbon emissions in the construction sector [5].

The promotion of activities in harmony with nature and ecology was formalised in 1987; the term 'sustainable development' was first introduced in the report titled "Our Common Future," created by the World Commission on Environment and Development. It was this committee that convened the Earth Summit in Rio de Janeiro in 1992. It is difficult to quote here all the documents adopted at that time that relate to climate protection, biodiversity, or forest protection and use, but also sustainable urban development. Dozens if not hundreds of major international conferences on sustainable urban design have been held around the world. It has been three decades of action with very little effect, because all these years, the world's most important decision-makers have not wanted to hear about the problems ahead of us by not respecting basic standards of environmental protection and ecology. The threats have been ignored for the benefit of global consumerism. Environmental consciousness emerged at the beginning of the 21st century when human activity led to irreversible changes on earth. One example of positive developments is China and its economic policy, which in recent years has taken a clear course towards sustainable development. However, it did not look so optimistic until several years ago. In terms of GDP size, China became the second-largest economy in the world at the beginning of the century. A poor country gave birth to an economic tiger that everyone has to reckon with. Everyone also wanted to cooperate, hoping for concrete profits. At that time, the Chinese built en masse, changed cities, built new ones. In 2012, it was typical brick construction with a monolithic or prefabricated structure, meeting the requirements of current regulations and standards; that year The Ministry of Housing and Urban-Rural Development of China (MOHURD) announced an ambitious plan for sustainable construction at a level of 24\% in 2020; in 2017, the targets have been revised by 2020. The new green building area across the country is expected to reach 2 billion square metres, or almost $50 \%$ of all residential and commercial investments completed in the year (Figure 1).

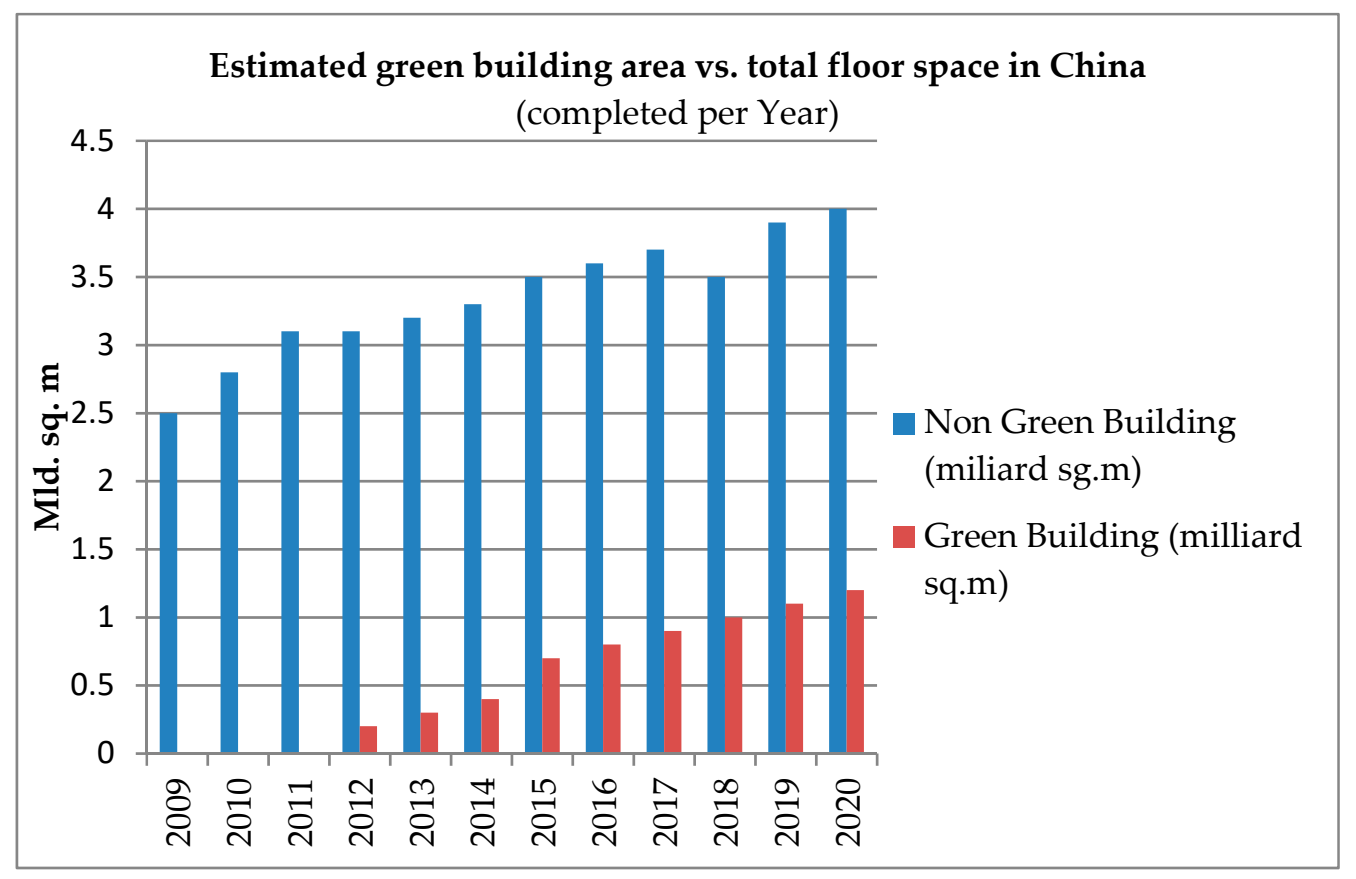

Figure 1. Estimated green building area versus total floor space in China. Source: Ministry of Housing and Urban-Rural Development of China (MOHURD). 
Regrettably, the visual change of cities took place to the detriment of their own identity. An example is Beijing, where historic low-rise residential buildings were demolished, replaced by multi-family buildings, sometimes several or several dozen floors high. No lessons have been learned from earlier demolitions, from the cultural revolution that abandoned the history and tradition of housing construction, in particular, which had lasted continuously for 800 years [6]. Sustainable development of cities is also non-material elements with a high emotional load, such as historical and cultural continuity, shaping our identity. Today, many companies producing building materials and technical equipment for sustainable, green, and passive buildings have their headquarters and production facilities in China. This includes cladding systems, glazing, heating and cooling of buildings, finishing materials and furniture, but also computers, servers, various types of control panels responsible for the operation of systems optimizing energy consumption and living comfort in buildings. There are also photovoltaic panels, wind turbines, and several other elements important for green architecture certification. Ironically, the country's economy is still the most energy-intensive of all countries in the world, and China is very reluctant to change its industrial pollution limits under pressure from other countries. The threats to a growth-oriented society-as China has experienced over the years-are primarily environmental and sociocultural ones. Environmental threats generate costs as a result of greenhouse gas emissions, environmental degradation, increasing use of non-renewable resources, abuse of renewable resources, and increased emissions of harmful substances and noise [7]. This is illustrated by the diagram of $\mathrm{CO}_{2}$ emissions from cement production. In 2015, the emissions reached 1.2 billion tonnes per year-as compared to "only" 45 million tonnes in the U.S. at the same time. The graph also shows that the peak growth in emissions occurred during the financial crisis that started in the USA in 2007 (Figure 2) [8].

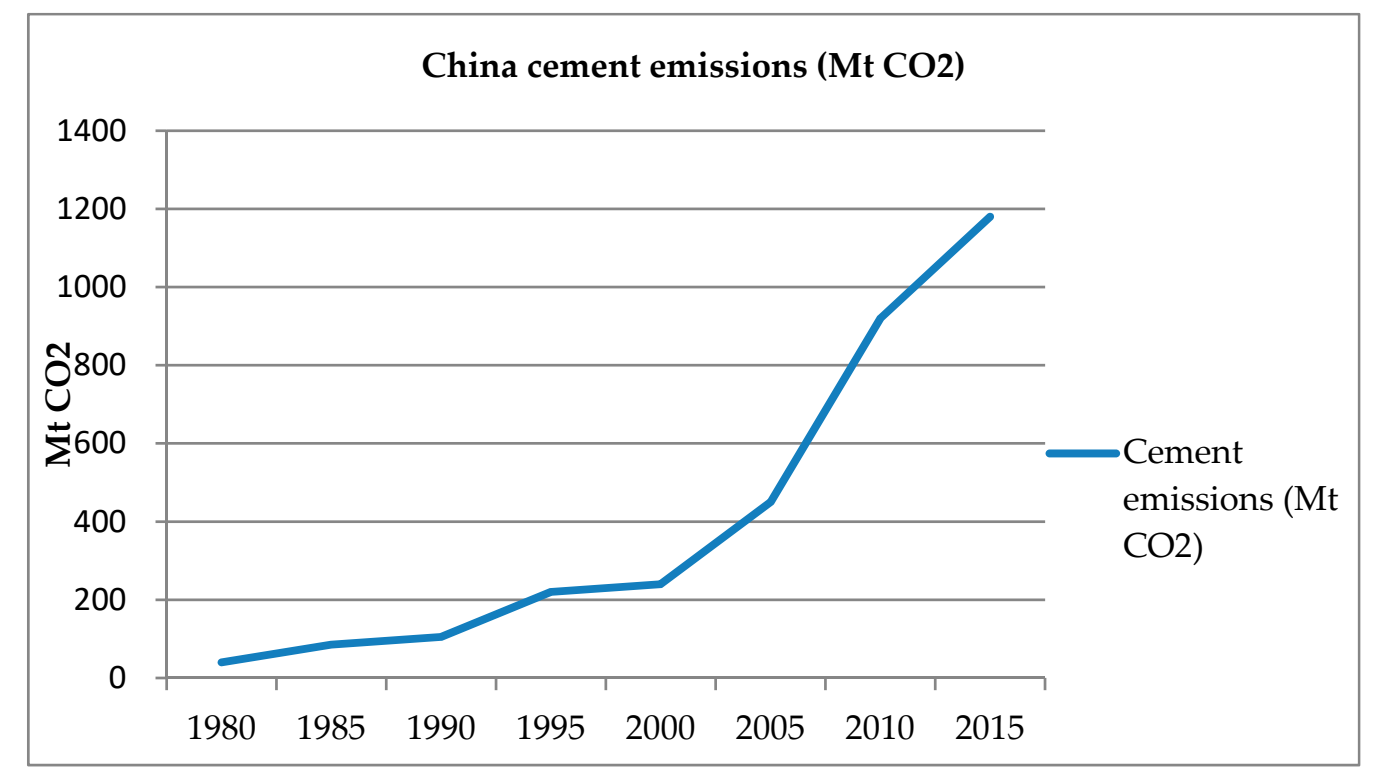

Figure 2. China cement emissions ( $\left.\mathrm{Mt} \mathrm{CO}_{2}\right)$. [Robbie, 2019]. Source: https://essd.copernicus.org/ articles/11/1675/2019/essd-11-1675-2019.pdf.

China has been growing rapidly for a long time, regardless of the cost to the surrounding nature. This has resulted in a huge increase in air, water, and soil pollution, which threatens human health and life. Research carried out by the World Bank, the World Health Organization, and the Chinese Academy of Environmental Planning said that environmental pollution in China is responsible for the premature death of between 350,000 and 500,000 people [7]. However, there came a time when it became clear that this model was no longer sustainable and new mechanisms of development solutions had to be developed which would also take into account environmental protection [7]. In China, the acquisition of modern technology was mainly due to the inflow of foreign direct investment 
and the related flow of knowledge. Since the 1980s, the country has pursued a deliberate policy ensuring that foreign corporations have access to its market in exchange for advanced technologies [9]. The cheap labour force, access to raw materials (oil, iron ore, non-ferrous metal ores, raw materials for fertilizer production) and the prospect of high profits have been the mainstay of Western capital for many years. However, rising production costs over time have resulted in the relocation of production to other countries of the Asian continent mainly. Some industries, primarily those related to new technologies, have remained, not always acting ethically. China is now the largest producer of various types of batteries for the electronics industry as well as batteries for electric cars, the most important element of sustainable urban development-zero-emission transportation. Cobalt is used in their production. However, the most popular electronics manufacturers such as Apple, Samsung, and Sony, manufacturers of electric cars, including Volkswagen, General Motors, Fiat, and Chrysler, have not been interested in the way cobalt used in their devices and cars is obtained for many years. According to a report by Amnesty International (2016) and AfreWatch, which deals with working conditions in cobalt mines in the Democratic Republic of Congo (DRC), where the largest supplies of this raw material come from, there are tens of thousands of children working in the mines with many as young as 7-year-olds among them [10]. After the report, some companies have responded appropriately, increasing monitoring of cobalt supplies; some like Microsoft did not react at all. To think about a sustainable living environment, environmental and even, as described above, ethical measures are of fundamental importance. We have less and less space for a healthy life every year. In 2019, the World Health Organisation (WHO) estimated that as much as 91\% of the world's population live in areas where poor air quality threatens life and health [11].

\subsection{Financial Crisis}

The environmental crisis has been growing for years; living with it has limited our vigilance in predicting the consequences. The financial crisis is different, with its severe negative economic and social consequences, felt by the majority of citizens of the country affected by the crisis. An event of global significance was the financial crisis which began in the USA with the collapse of subprime loans to citizens to purchase real estate [12]. The spectacular collapse of Lehman Brothers Bank has only completed the formalities, spreading the financial crisis and, consequently, the economic crisis to virtually all countries of the world. In the USA alone, more than 8.7 million people lost their jobs, especially in male-dominated industries such as construction and manufacturing. The recession lasted three years [13]. The chart below shows the scale of the market collapse in the long run with the example of traditional single-family house construction in the U.S., and the optimistic trend of green construction (Figure 3) [14]. The recovery from the crisis has positioned these two types of single-family buildings in completely different proportions. An authoritative report by Smart Market: National Green of Home Builders -NAHB: Green Multifamily and Single-Family Homes 2017, indicates that, although the share of green single-family houses was only $2 \%$ in 2005 , it rose to $33 \%$ in 2017 . It was expected to rise to $38 \%$ in 2019 and continue to rise to $44 \%$ by 2022 [15].

It can be assumed that it was the financial crisis that drew the attention of hundreds of thousands of Americans to a more rational way of investing in their homes, making them not only greener, but also cheaper in their later exploitation, and that is sustainable construction.

Although the above optimistic example of a change in the social attitude towards the construction of single-family houses is not a reflection of the global processes of change that took place after 2007, it is a harbinger of correct actions taking into account the ecological and economic aspect, which Rutkowska-Podolska wrote about in 2016. 


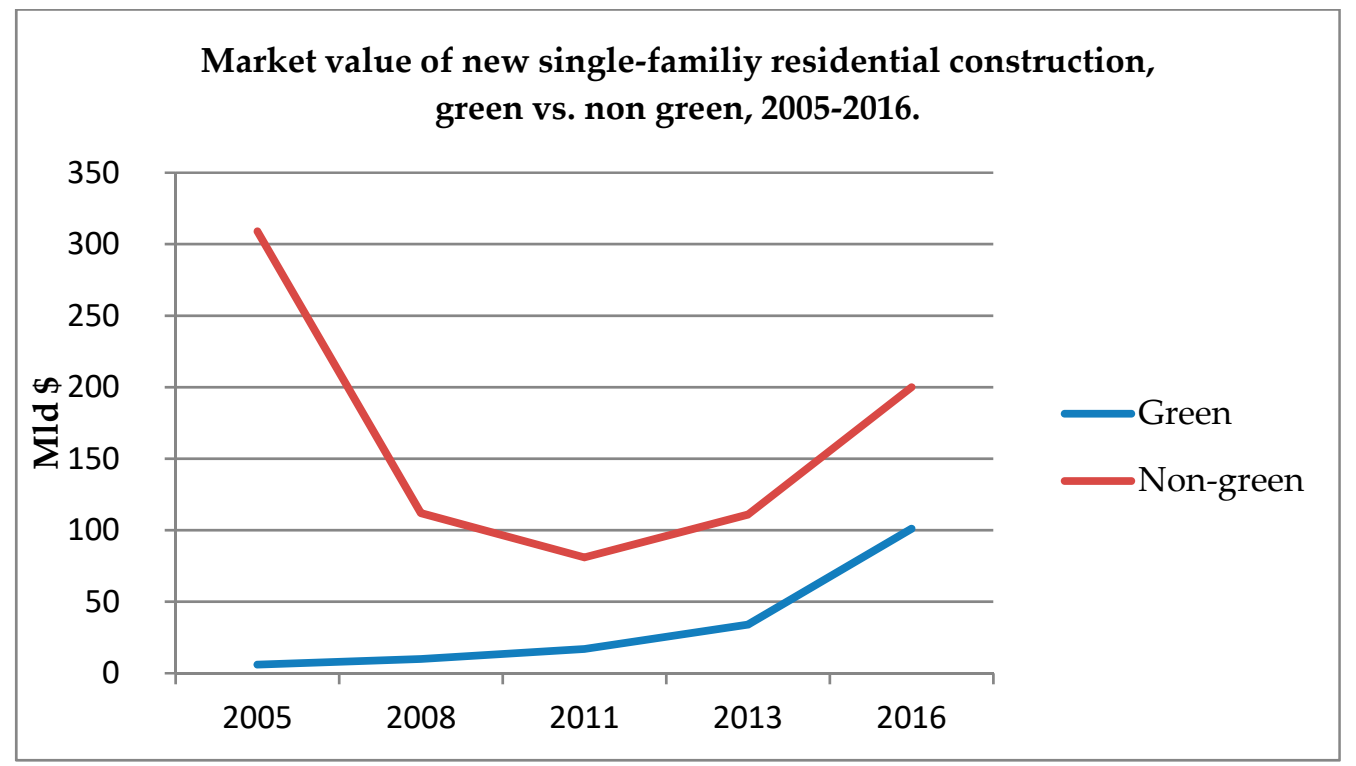

Figure 3. Market value of single-family residential construction, green versus non-green, 2005-2016. Source: The Center for Construction Research and Training in USA.

However, the economic crisis hinders solving the world's environmental problems and exacerbates the environmental crisis, which in turn further increases the total losses caused by the economic and financial crisis. This creates a feedback effect that is dangerous for the economy. Therefore, to maximise the quality of life and minimise human pressure on the planet, it is important to consider economic, ecological, and sociocultural aspects [16]. Unfortunately, during the recovery from the economic crisis, part of the economy is focused on improving macroeconomic indicators as soon as possible, the aim being to reach pre-crisis levels as a rebound point. Under these circumstances, is caring for the environment an encouraging factor? Unfortunately, the answer is no. The graph below shows the $\mathrm{CO}_{2}$ emissions of the cement industry in the U.S. during the years of the financial crisis (Figure 4) [8].

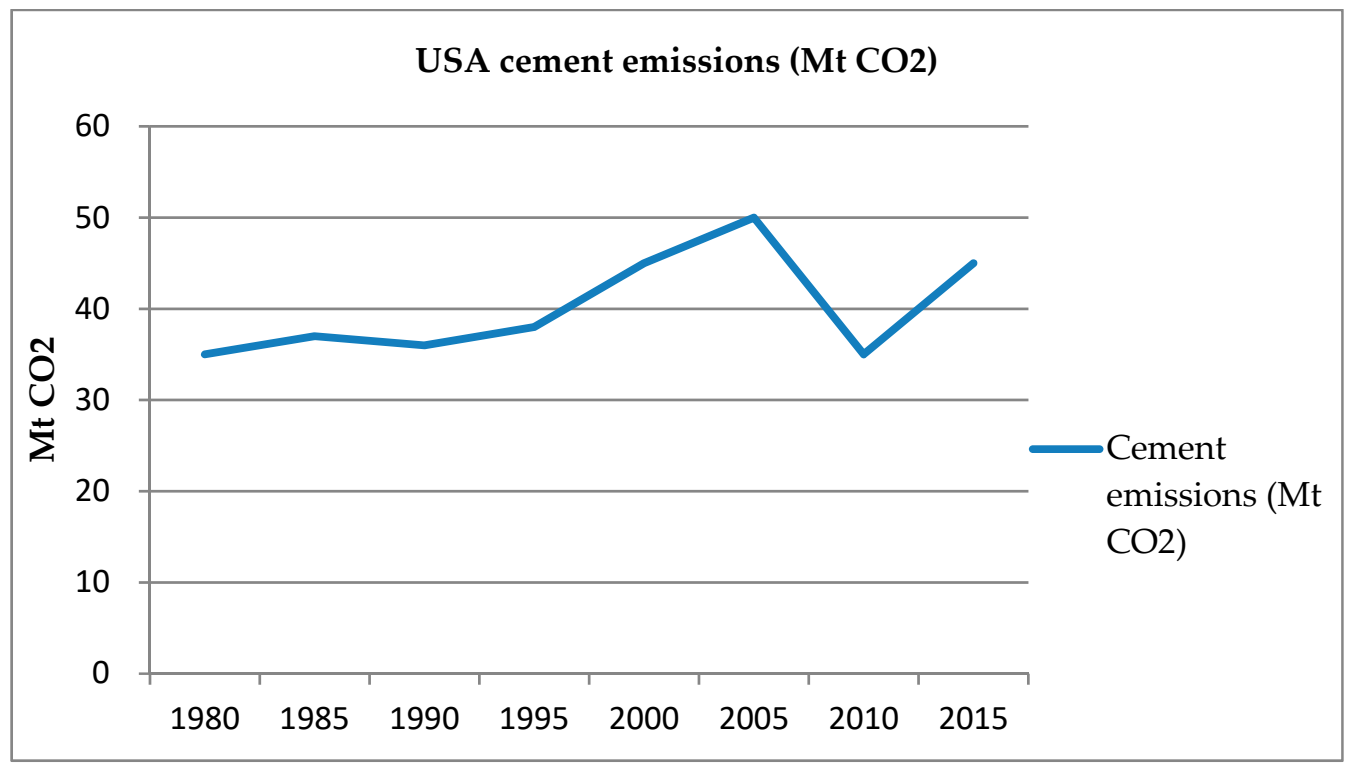

Figure 4. USA cement emission $\left(\mathrm{Mt} \mathrm{CO}_{2}\right)$ [Robbie, 2019]. Source: https://essd.copernicus.org/articles/ 11/1675/2019/essd-11-1675-2019.pdf.

The visible slump is typical for most of the world's cement producers outside China, as already noted (Figure 2). In those years, China competed with its goods on the world markets mainly through 
price, so it can be presumed that the global construction industry relied on a Chinese product to save money when recovering from the crisis. The product paid for came with a high mortality rate due to environmental pollution and underestimated emission standards of harmful factors into the atmosphere. Even the greenest buildings, certified office buildings, residential buildings, schools, trade, etc., completed at that time raise ethical concerns once again. Since 2014, when the crisis and its consequences became averted, sales of Chinese cement have been steadily decreasing and will reach 2.14 million tonnes in 2020 [17]. Given the current state of the world caused by the coronavirus, there are already many warnings in the Western media about China's renewed domination after the crisis. The mechanism of action may be the same as described above. The consequence of civilization is man's drive for profit at all costs and a lack of sensitivity to nature, which in turn has led to an ecological crisis [16].

\subsection{Covid-19 Humanitarian Crisis}

The date of November 17, 2019, will be recorded in history books all over the world. It was on that day that a 55-year-old man, described after a time as patient " 0 ," became infected with the SARS-CoV-2 coronavirus. By the end of December, there were already 60 patients, but the worst was to come a little later. Within only 5 months, the virus attacked all over the world. By the end of May 2020, there were already more than 5 million people sick and over 328,000 confirmed deaths due to the infection. Currently, there is no country where its health care system can control the virus because there is not yet an effective cure to fight the infection while for procedural reasons of laboratory testing, an effective vaccine may not be effective until next year. The only effective protection against infection is isolation from the environment in which there may be other people. This is what has happened, those who can work remotely, work from home, those who cannot, like a whole host of services that look after our safety and health, do it with personal protective equipment (PPE). Organisational prevention and protection measures were developed and implemented to minimise the likelihood of exposure to SARS-CoV-2 [18]. Some companies have discontinued their operations. Some branches of the economy are going bankrupt or will go bankrupt in the foreseeable future; the whole tourist and hotel sector, land and air transport are going into decline [19]. At the end of March, just at the beginning of the pandemic, stock exchanges around the world were reaching levels not seen for 30 years, the main index on Wall Street on March 17 alone lost over $12 \%$. The crisis caused by the coronavirus has already put 38.6 million Americans in line for benefits, i.e., one in five citizens has lost their jobs. At the end of April, unemployment in the U.S. was $14 \%$, and it could actually be much higher. On May 5, Reuters published Federal Reserve FED calculations according to the new U-Cov unemployment rate, its value exceeds 30\%. All over the world, where COVID-19 appeared, as this is the official name of the coronavirus announced by the World Health Organization, the economic situation looks similar or hardly better. The European data does not show such a drastic desolation of the labour markets in individual countries. The unemployment rate is mostly below $10 \%$ with Spain leading with 14\% [20]. However, the readings come from March, when the spread of the disease was just developing. The actual gross domestic product looks similar. In the entire European Union, GDP is forecast to fall to $-7.7 \%$. In the first half of 2020 , the U.S. economy shrank by $5.0 \%$ year-on-year and the Chinese economy by $6.8 \%$ [21]. The scale of the decline in several selected European countries in relation to the previous year 2019 is shown in the graph below (Figure 5) [22]. 


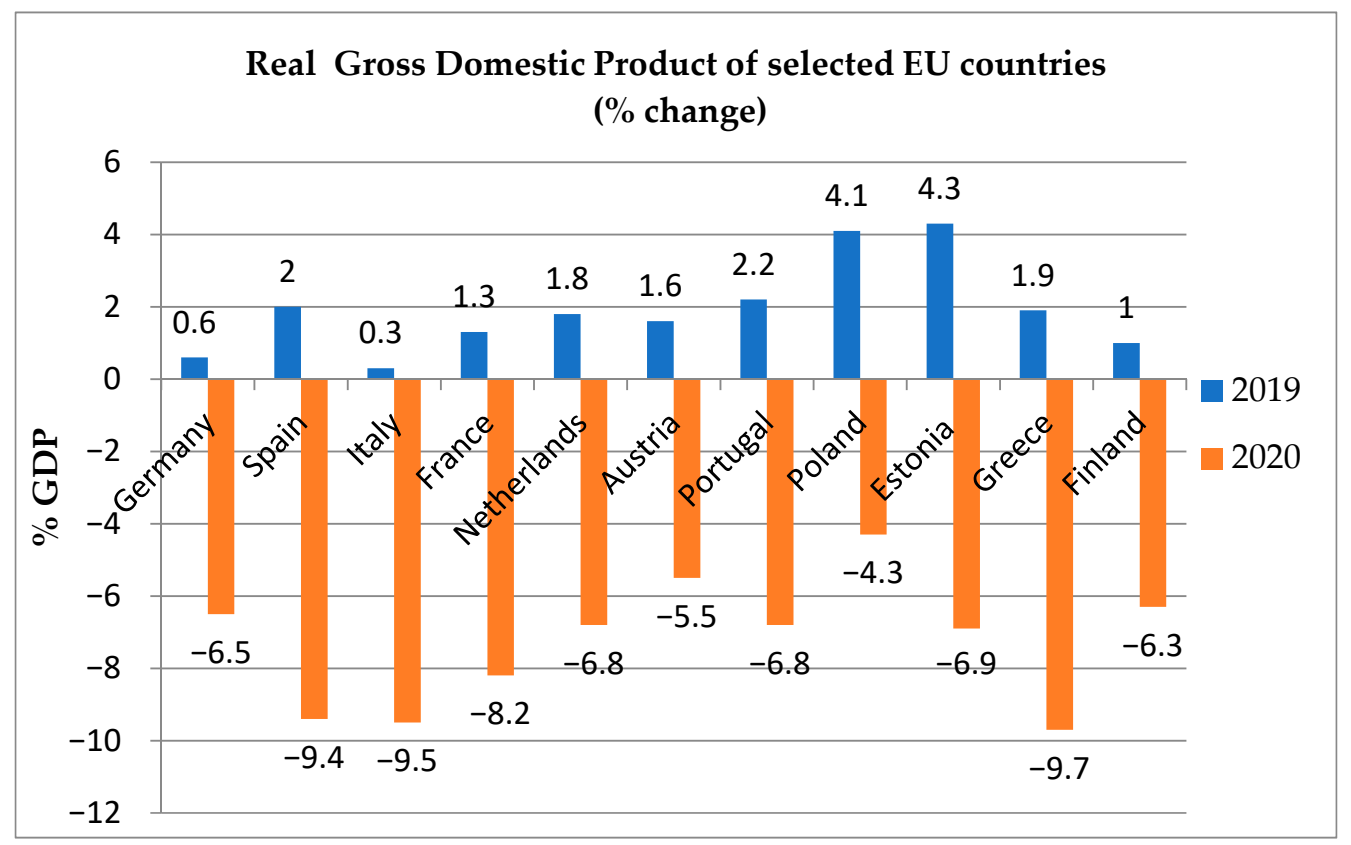

Figure 5. Real Gross Domestic Product of selected EU countries.

What will be the economic impact of the pandemic? This is not easy to predict, especially as there is a lack of historical references. Periods of high unemployment and low interest rates are the right time for new investments in low-carbon infrastructure this time, as the next step towards a transition to clean energy [23]. This area of government interest should encompass concern for our future. We have been given one more chance, perhaps the last one to gain public awareness that sustainable development is the direction without an existing alternative today.

\section{Discussion}

The environmental crisis is the result of human activity, driven by convenience and the lust for profit; we turned a blind eye to the deteriorating indicators of our ecosystem, the financial crisis was a response to overheated economic indicators. We continue to react poorly to rising sea and ocean levels, to melting ice caps at the poles, and the disappearance of animal species is part of our daily narrative. The crisis triggered by COVID-19 is a response to overpopulated cities, our greed, and selfishness. It is now to be feared that the next pandemic will turn out to be more deadly and even more difficult to combat. According to experts, we have a decade left to wake up and take radical action. The actions involve sacrifices even though we do not like anything that limits the comfort of the life we are used to. Our planet no longer has the capacity to self-purify and self-create biocenoses and ecosystems, the ecological balance no longer exists. Over two decades ago, Zbigniew Kuderowicz wrote about ecological alienation that occurs when "...the state of homeostasis between man and the environment is disturbed when the destroyed biosphere ceases to be conducive to the maintenance and development of human life and instead carries with it the possibility of its damage and destruction. Ecological alienation as a state of estrangement between man and the environment means that the bonds of mutual interaction between them have been broken, it means that a sinister barrier has grown between them" [24]. Over 30 years have passed since the report "Our Common Future." Mankind has not become fascinated with sustainability; although the increasing number of weather anomalies are beginning to affect us directly, the cause and effect relationship is obvious. The high costs of sustainable construction have been seen over the years as a fad of the rich who can afford the luxury of owning a home that cares about safety, health, and the wallet of its owner. The high price of the product deterred potential investors. Despite its many advantages, sustainable construction still has not ceased to be more expensive than traditional construction. Perhaps at a time when we spend most of our 
time at work and treat the house as a bedroom, its ecological qualities are not essential. Against this background, China is sending a positive signal that effective change is possible. The world's largest polluter is becoming a leader in promoting sustainable development; in just 15 years, from 2005 to 2018 , the intensity of greenhouse gas emissions has been reduced by 40-45\%, and by 2030 it is expected to be $60-65 \%$, as can be read in the Center for Strategic and International Studies report. Of note, $45 \%$ of all electric cars are already on the streets of Chinese cities today. According to the report, China accounted for $45 \%$ of the world's renewable energy production growth in 2018. For all those interested in sustainable development, China today represents an example of implementing effective measures on a scale unimaginable in most countries in the world. Our life is dominated by economy and comfort. We leave our fascination with green architecture to those who, with the calculator in their hands, count the amount of electricity saved, the amount of heat energy recovered, the litres of rainwater used. While green/sustainable construction in housing so far accounts for only a small part of total residential construction, sustainable construction in public buildings has dominated the market. The disparities between residential and public buildings are not good. For example, Poland, which is the leader among 14 countries of Central and Eastern Europe, has 51\% of all certified facilities in the area. The share in 2019 in the total certified area was 50.1\% for offices, 32.1\% for commerce, $15.1 \%$ for industry, $1.4 \%(!)$ for housing, and at the very end, $1.1 \%$ for hotels and $0.1 \%$ for schools [25]. Without green housing, it will be difficult to compete with the achievements of public architecture. As China has shown, environmental awareness and, in particular, people's concern for their own health, are needed for this; without these elements, society appears not to respond to possible threats.

The humanitarian Covid-19 crisis has lasted for only a few months; today, nobody knows what the world economy will look like in 3 or 6 months. One thing is certain, the economic crisis will be long-lasting and extremely painful, unemployment is still rising. This reminds us of the beginning of the financial crisis in the U.S. in 2007. The only difference is that the coronavirus crisis will be much more powerful in all respects and the financial, economic, and human losses are difficult to estimate. This makes it all the more important for the communities of countries affected by the pandemic to prepare for a return to sustainable growth, taking into account, inter alia, the ecological and digital transformation and drawing all the lessons from the current crisis [26]. There are numerous reasons for action, and even those that seem to be just an imperative to protect our health may soon trigger changes in the design of public, residential, and open recreational areas. An example here is the recommendation to keep social distance. The main way of Covid-19 coronavirus transmission is the droplet route. This means that we can contract the infection by being close to a person who is ill and coughing and sneezing in our company. In order to protect ourselves from the infection, WHO recommends keeping a minimum of 1 metre of social distance from the other person. Professor Lydia Bourouiba at the Massachusetts Institute of Technology (MIT), who deals with the dynamics of coughing and sneezing processes in the 'Journal of the American Medical Association,' argues in her paper (12 May 2020) that the right distance should be up to 7-8 metres. The time before the pandemic has gone down in history irreversibly; now we have to learn to live, work, and even dwell in a completely different way. A new way of shaping public space in public buildings should be considered, ensuring its safe use by keeping a proper distance from another person. The same applies to the external public space of streets, squares, and parks. Working remotely, we spend much more time in our own houses and flats. We have converted part of our own private living space into an office, a shop, and even a lecture hall. We spend more time in front of computers than before the pandemic. Also, our working time has been partially disrupted. The work/life balance is lost somewhere. The existing thinking about the function of the house/flat should be revised. The multidimensionality of sustainability should also address those aspects that may not translate directly into sustainable construction, but their potential and the dynamics of change suggest that this will happen. Due to the need to maintain social distance, it is not difficult to predict a scenario in which some of the most modern office space with a full list of certificates will never reach full occupancy again, and remote work will be more secure and economically viable for both the office owner and the employee. A new way of using the house/apartment as a place of rest and 
work should revive the discussion about the need to invest in sustainable construction-construction with low emissions, cheap to operate and, above all, comfortable to stay in for a long time. This is a very complex issue and needs the multidisciplinary and multi-sectoral attention of specialists from different scientific fields. No one can guarantee that in a dozen or so years' time there will be no other virus, even a more deadly one, which will exclude us from public life not for weeks, but for months or even years. For the sake of our mental health, we should prepare ourselves for this contingency, which is why it seems so important to take a new look at housing, taking into account all elements related to long-term social isolation. Architecture is facing great challenges, likewise the governments of most countries in the world, Covid-19 is not a precedent, it is the first pandemic, which will be followed by others, it is only not known when. That is why it is necessary to take advantage of the opportunity offered by the unity of mankind in the face of the deadly disease and to promote all those elements of modern life that guarantee safe working and living conditions. Sustainable construction is one such element. It is important not to miss this opportunity in an attempt to return to normality.

\section{Conclusions}

Sustainability is a very capacious word; it contains all the aspects related to social well-being and the proper relationship between man and nature. The following conclusions can be drawn from a multi-threaded analysis of the issue under consideration:

- in order to emerge from the environmental crisis, the governments of all countries of the world must set themselves high environmental requirements and implement them effectively; an example of such consistent action is China. Unprecedented achievements in reducing greenhouse gas emissions, the use of renewable energy sources are setting an example for other countries. However, this requires establishing long-term strategic plans and the consistency of their implementation. In times of environmental crisis, education at every level and international solidarity have failed, as evidenced by the described transfer of investments of rich Western countries to countries with the lowest ecological awareness;

- business and institutional rather than technical factors are at the root of the fact that, so far, sustainable construction has not led to a final breakthrough; according to the data mentioned above, after the financial crisis in 2007 , residential construction continued to invest mainly in traditional construction technologies, presumably, after analysis of data and graphs, made from cheaper materials and products manufactured in emerging markets such as China; here, too, using lower environmental awareness, current legislation and growing economic ambitions in society. The 2007 crisis proved to be ineffective in promoting sustainable construction, perhaps because it did not affect our lifestyles, work and living conditions and our health;

- insufficiently transparent actions of market tycoons and insufficient social sensitivity to unethical behaviour of companies from the electronics industry, suppliers of hardware equipment to control elements and installations limiting $\mathrm{CO}_{2}$ emissions in buildings;

- the Covid-19 pandemic has changed the way we work and rest, has turned upside down the old patterns and ways of using public and private spaces; closed for weeks in our own homes and offices, we are learning to live anew; in the post-covid world, we want to live safely, healthily and especially comfortably-the topic of sustainable housing is becoming more relevant than ever before. It is now up to us whether, while returning to normality, we will miss another opportunity offered by sustainable construction, or whether, by drawing conclusions, we will begin to shape our environment in the most responsible way possible.

Four years ago, in 2015 on the famous TED Talks channel, Bill Gates warned that the greatest threat to humanity will not be global armed conflicts, but diseases caused by viruses. Now his prophecy is being fulfilled before our eyes. Yet, being a scientist, the author is convinced that we will come out of this catastrophe much smarter and more open to all activities related to our future, in which sustainable construction should have its significant place [27]. 
Funding: This publication has received financial support from the Polish Ministry of Science and Higher Education under subsidy for science.

Acknowledgments: The author would like to express his gratitude to all reviewers and journal editors for their insightful comments and suggestions on how to improve the manuscript.

Conflicts of Interest: The author declares no conflict of interest.

\section{References}

1. Carrington, D. Halt destruction of nature or suffer even worse pandemics, say world's top scientists. The Guardian, 27 April 2020.

2. Kostecka, J. Retardacja Tempa Życia i Przeksztatcania Zasobów Przyrody—Wybrane Implikacje Obywatelskie; Wydawnictwo Inżynieria Ekologiczna: Lublin, Poland, 2013; pp. 38-52.

3. Global $\mathrm{CO}_{2}$ Emissions in 2019. Available online: https://www.iea.org/articles/global-co2-emissions-in-2019 (accessed on 15 May 2020).

4. New Report: The Building and Construction Sector Can Reach Net Zero Carbon Emissions by 2050. Available online: https://www.worldgbc.org/news-media/WorldGBC-embodied-carbon-report-published (accessed on 15 April 2020).

5. Huang, L.; Krigsvoll, G.; Johansen, F.; Liu, Y. Carbon emission of global construction sector. Renew. Sustain. Energy Rev. 2017, 81, 1907-1916. [CrossRef]

6. Kapecki, T. Wyprawa do Chin. In Wiadomości ASP 5; Akademia Sztuk Pięknych w Krakowie: Kraków, Poland, 2016; pp. 72-83.

7. Gacek, Ł. Zielona Energia w Chinach Zrównoważony Rozwój Ochrona Środowiska Gospodarka Niskoemisyjna; Wydawnictwo Uniwersytetu Jagiellońskiego: Kraków, Poland, 2015; pp. 15-87.

8. Robbie, M.A. Global $\mathrm{CO}_{2}$ emissions from cement production 1928-2018. Earth Syst. Sci. Data 2019, 11, 1650-1710.

9. Łasak, P. Procesy Umiędzynarodowienia Przemystu Samochodowego. Rola Rynków Wschodzacych; Wydawnictwo Uniwersytetu Jagiellońskiego: Kraków, Poland, 2013; p. 101.

10. Industry Giants Fail to Tackle Child Labour Allegations in Cobalt Battery Supply Chains. Available online: https:/www.amnesty.org/en/latest/news/2017/11/industry-giants-fail-to-tackle-childlabour-allegations-in-cobalt-battery-supply-chains/ (accessed on 18 April 2020).

11. Air Pollution. Available online: https://www.who.int/airpollution/en/ (accessed on 18 April 2020).

12. Sadorsky, P. Energy Related $\mathrm{CO}_{2}$ Emissions before and after the Financial Crisis. Sustainability 2020, $12,3867$. [CrossRef]

13. Puzzanghera, J. Economy has recovered 8.7 million jobs lost in Great Recession. Los Angeles Times, 6 June 2014.

14. McGarvey, S.; Booker, B.; Stafford, E. The Chart Book: The US Construction Industry and the Workers; CPWR-Centre for Research and Training 04/01: Silver Spring, MD, USA, 2013; p. 9.

15. Jones, S.; Laquidara-Carr, D. Smart Market: National Green of Home Builders 'NAHB: Green Multifamily and Single-Family Homes; Dodge Data \& Analytics: Hamilton, OH, USA, 2017.

16. Rutkowska-Podołowska, M. Kryzys gospodarczy i jego wpływ na zrównoważony rozwój. Czas. Ekon. Środowisko 2016, 1, 16.

17. Cement Consumption in China from 2010 to 2020. Available online: https://www.statista.com/statistics/ 1042516/chinese-cement-consumption/ (accessed on 11 April 2020).

18. Cirrincione, L.; Plescia, F.; Ledda, C.; Rapisarda, V.; Martorana, D.; Moldovan, R.; Theodoridou, K.; Cannizzaro, E. COVID-19 Pandemic: Prevention and Protection Measures to Be Adopted at the Workplace. Sustainability 2020, 12, 3603. [CrossRef]

19. Chang, C.; McAleer, M.; Ramos, V. A Charter for Sustainable Tourism after COVID-19. Sustainability 2020, 12, 3671. [CrossRef]

20. Kieszek, N. Rynek Pracy w Europie w Dobie Koronawirusa, Czyli Jak Mocno Wzrośnie Bezrobocie w Wybranych PańStwach. Available online: https://strefainwestorow.pl/artykuly/gospodarka/20200430/ bezrobocie-w-europie-epidemia-koronawirus (accessed on 31 May 2020).

21. 20 Million Economic Indicators for 196 Countries. Available online: https://tradingeconomics.com (accessed on 28 May 2020). 
22. Oto Państwa UE, Które Czeka NajwięKsze ZałAmanie Gospodarcze. Available online: https://forsal.pl/gospodarka/galerie/1474759,duze-zdjecie,2, prognozy-ke-pkb-strefy-euro-skurczysie-o-7-7-proc-najwieksze-zalamanie-na-poludniu.html (accessed on 31 May 2020).

23. Florizone, R. Three Ways the Coronavirus is Shaping Sustainable Development. The Knowledge to Act. The International Institute for Sustainable Development (IISD). Available online: https://www.iisd.org/about/ about-iisd (accessed on 26 May 2020).

24. Kuderowicz, Z. Filozofia Wobec Zagrożeń Cywilizacyjnych; Wydawnictwo Studia Filozoficzne: Warszawa, Poland, 1988; p. 153.

25. Kuczera, A. Certyfikacja Zielonych Budynków Liczbach; Raport Polskiego Stowarzyszenia Budownictwa Ekologicznego, PLGBC: Gliwice, Polska, 2019; p. 6.

26. Piszczatowska, J. Żadnego Schodzenia z Zielonej Ścieżki. Mimo Koronawirusa Nowy Zielony Ład Pozostaje Flagowym Projektem UE. Available online: www.green-news.pl,27.03.2020 (accessed on 23 May 2020).

27. The Next Outbreak? We're Not Ready. Available online: https://www.ted.com/talks/bill_gates_the_next_ outbreak_we_re_not_ready?language=pl (accessed on 28 May 2020).

(C) 2020 by the author. Licensee MDPI, Basel, Switzerland. This article is an open access article distributed under the terms and conditions of the Creative Commons Attribution (CC BY) license (http://creativecommons.org/licenses/by/4.0/). 